\title{
Seasonal occurrence at a Scottish PSP monitoring site of purportedly toxic bacteria originally isolated from the toxic dinoflagellate genus Alexandrium
}

\author{
K. TÖBE ${ }^{1}$, C. FERGUSON ${ }^{2}$, M. KELLY' S. GALLACHER ${ }^{2}$ AND L. K. MEDLIN ${ }^{1}$ \\ ${ }^{1}$ Department of Biological Oceanography, Alfred Wegener Institute, Bremerhaven, Germany \\ ${ }^{2}$ Fisheries Research Services Marine Laboratory, Aberdeen, Scotland, UK
}

(Received 21 August 2000; accepted 5 April 2001)

\begin{abstract}
There is increasing evidence that bacterial-algal interactions play a role in Harmful Algal Bloom (HAB) ecology. Bacteria that are associated with bloom-forming algal species, specifically toxic dinoflagellate algae, have been implicated in the production and biotransformation of paralytic shellfish toxins (PSTs). To clarify the role that these bacteria may play in the production of PSTs, it is desirable to identify and localize the bacteria associated with the dinoflagellates and enumerate them during the course of the algal blooms that the toxic dinoflagellates produce. Because 16S rRNA-targeted probes offer the possibility of both, we previously made and tested probes for some putatively toxigenic bacteria isolated from cultures of the PSP-related dinoflagellates Alexandrium tamarense, A. affine and A. lusitanicum. The bacteria isolated from the dinoflagellates belong primarily to the alpha-proteobacterial group of Roseobacter and the gamma-proteobacterial group of Alteromonas. Here, we report the successful application of these probes to Lugol's-fixed seawater samples. We detected these bacteria in high numbers in the water column when Alexandrium spp. were both present and absent, and during periods when mussels contained PSTs.
\end{abstract}

Key words: dinoflagellates, paralytic shellfish toxins, PSP, purportedly toxic bacteria, 16S rRNA probes

\section{Introduction}

Paralytic shellfish poisoning (PSP) is a life-threatening illness in humans who consume seafood contaminated with paralytic shellfish toxins (PSTs) (Kao, 1993). These are potent neurotoxins composed of the primary toxin, saxitoxin (STX), and at least 20 known derivatives that vary in toxicity (Oshima, 1995). Bivalve molluscs become contaminated with PSTs primarily through filter-feeding some species of PST-producing dinoflagellates (viz., four species of the dinoflagellate genus Alexandrium, Pyrodinium bahamense var. compressum and Gymnodinium catenatum; Cembella, 1998). PSTs are also known to be produced by three species of cyanobacteria: Aphanizomenon flos-aquae (Mahmood \& Carmichael, 1986), Anabaena circinalis (Negri et al., 1997) and Lyngbya wollei (Onodera et al., 1997), and by the calcareous rhodophyte, Jania sp. (Cembella, 1998).

A bacterial origin of PSTs was suggested by Silva (1982) based on the presence of bacteria-like particles within dinoflagellate cells. A PST-producing intracellular bacterium named 'Moraxella' sp. was

Correspondence to: Linda Medlin.

e-mail:Lmedlin@awi-bremerhaven.de subsequently isolated from Alexandrium tamarense (Kodama et al., 1988; Kodama, 1990) and bacteria were observed within the dinoflagellate nucleus (Kodama et al., 1990a). This bacterium was later identified as belonging to a new genus of alphaProteobacteria rather than to Moraxella, a gammaProteobacterium (Kopp et al., 1997). However, claims of intracellular bacteria have not been substantiated by other researchers (Doucette et al., 1998 and references therein), although research on Alexandrium cultures has shown the presence of bacteria-like structures underneath the theca ( $A$. lusitanicum; Franca et al., 1995, 1996) or attached to the theca (Prorocentrum micans; Rausch de Traubenberg \& Soyer-Gobillard, 1990). Most recently, Lewis et al. (2000) and Córdova et al. (2001) have demonstrated unequivocally intracellular bacteria in various species of Alexandrium using several different detection methods. Since the early reports, heterotrophic bacteria isolated both from cultures of toxic dinoflagellates and from field samples have been reported to synthesize PSTs, with toxins detected by a number of methods both biological and chemical, including Confocal Laser Scanning Microscopy. However, despite a large body of data, definitive spectral evidence for PST 
production by bacteria remains lacking and the bacteria are best described as purportedly toxic bacteria (Kodama et al., 1990; Ogata et al., 1990; Doucette \& Trick, 1995; Gallacher \& Birkbeck, 1995; Levasseur et al., 1996; Gallacher et al., 1997; Gallacher \& Smith, 1999 and references therein; Córdova et al., 2001).

It has also been suggested that bacteria may contribute to dinoflagellate toxicity indirectly via mechanisms that are currently unknown, although bacterial adhesion to the dinoflagellate cell wall has been suggested (Gallacher \& Smith, 1999). It is well established that the phenotypic properties of bacteria may be dramatically altered upon attaching to a surface (Costerton et al., 1995). In the case of PSTs, Doucette \& Powell (1998) demonstrated that bacterial enhancement of dinoflagellate toxicity levels was contingent upon presumed physical contact between the bacterium Pseudomonas stutzeri and the dinoflagellate $A$. lusitanicum. How the bacterium might affect dinoflagellate toxicity levels if they occur intracellularly remains conjectural. However, Alexandrium species are not known to phagocytose bacteria directly (Legrand \& Carlsson, 1998). Therefore, perhaps not surprisingly, claims of intracellular bacteria have not been widely substantiated by other researchers (Doucette et al., 1998 and references therein). However, Córdova et al. (2001), using a vitality test, have demonstrated that intracellular bacteria in $A$. catenella are alive and can divide. It is also of interest to note that dinoflagellate bacteria have been shown to biotransform PSTs (E. A. Smith, personal communication), although the effect of adhesion or intracellularity on this process has not been investigated. Nevertheless, describing the spatial relationship between bacteria and host algae is essential to understand any mechanism by which bacteria might modulate algal toxin production, either extracellularly or intracellularly.

One of the first steps in investigating this relationship is to identify the bacterial population associated with dinoflagellates. Recent studies have shown that the dinoflagellate microflora in laboratory culture tends to be restricted to the alphaProteobacteria (primarily Roseobacter spp.), gamma-Proteobacteria (mainly Alteromonas spp.) and to the cyto-subclasses of the Cytophaga among the Eubacteria (Hold et al., in press). It is also important for understanding of bacteria/dinoflagellate interactions and PST production to conduct studies in the environment. However, progress in this area has been slow and limited to a few publications relating to the detection of PSTs in bacterial-sized fractions in seawater (Kodama et al., 1990b; Sakomoto et al., 1992; Levasseur et al., 1996). Visualizing individual bacterial cells through in situ hybridization of fluorescently labelled, taxon- specific ribosomal RNA (rRNA) probes is one way of furthering these investigations. Ribosomal RNA probes are so designed that they can be used to detect strains of certain bacterial species (Amann et al., 1996). Here we describe the use of rRNA probes (Brinkmeyer et al., 2000) for in situ identification in field material of bacteria previously isolated from laboratory cultures of Alexandrium tamarense (Hold et al., in press), including several putatively toxigenic bacterial strains. The abundances of the bacteria were traced through integrated water column samples taken at designated monitoring sites at the Orkney Islands, Scotland, by applying rRNA probes designed to be specific for the bacterial clade and species to which these dinoflagellate bacteria belong (Brinkmeyer et al., 2000). The abundance of the dinoflagellate bacteria, including purportedly toxic strains, was compared with the total counts for Alexandrium spp. and with mussel toxicity.

\section{Materials and methods}

\section{Sample sites}

Integrated water samples were collected using a $10 \mathrm{~m}$ hose at several different sites at the Orkney Islands (see Fig. 2), immediately fixed in acid Lugol's preservative (Throndsen, 1978) and then transferred to brown bottles. Between samplings, the hose was flushed before the next sample was taken. Most samples were taken at Scapa and String, whereas four other sites were randomly sampled throughout the 1999 monitoring season (see Fig. 2, Table 2). The phytoplankton-monitoring programme of the FRS Marine Laboratory in Aberdeen, UK, analysed these samples in 1999. A modification of normal monitoring procedure was implemented in attempts to maximize the number of bacteria recovered in the settled sample. This involved allowing the samples to settle for 1 week, after which $900 \mathrm{ml}$ of supernatant was removed to give the 'supernatant sample'. The bottom $100 \mathrm{ml}$ was allowed to settle for a further $4 \mathrm{~h}$. These were examined by inverted light microscopy and the number of Alexandrium spp. cells recorded.

For the purpose of bacterial analysis, fractions from both the settled and supernatant (approximately $40 \mathrm{ml}$ of total seawater) were examined because a preliminary study showed that not all the bacteria present in the water column would settle after 1 week in a settling chamber. We examined 41 samples collected approximately weekly between February and November 1999 and stored in brown bottles at $4{ }^{\circ} \mathrm{C}$ until analysed.

\section{Mouse bioassay}

The mouse bioassay procedure was performed in accordance with the official mouse bioassay methodology (AOAC, 1990) for the detection of PSP in shellfish by FRS Marine Laboratory as part of the Scottish monitoring programme. 
Table 1. Sequences of the oligonucleotide probes used in this study, with protocol details for detection

\begin{tabular}{|c|c|c|c|}
\hline Probe & Sequence & $\begin{array}{l}\text { Compensating \% } \\
\text { formamide }\end{array}$ & $\begin{array}{l}\mathrm{NaCl}(\mathrm{M}) \text { in } \\
\text { wash buffer }\end{array}$ \\
\hline Eubacterial probe 338R (Amann et al., 1990) & 5'-ACT CCT ACG GGA GGC AGC-3' & 20 & $0 \cdot 9$ \\
\hline A. Roseobacter-clade/536R & 5'-CAA CGC TAA CCC CCT CCG-3' & $18 \%$ & $0 \cdot 27$ \\
\hline Competitor for Roseobacter-clade/536R & 5'-CAA CGC TAG CCC CCT CCG-3' & $18 \%$ & $0 \cdot 27$ \\
\hline B. $407-20 / 1446 \mathrm{R}$ & 5'-GTC CGC TGC CTC AAA AGT T-3' & $10 \%$ & $0 \cdot 45$ \\
\hline C. $667-19 / 1241 \mathrm{R}$ & 5'-TAA CCC ACT GTA GAT GCC-3' & $8 \%$ & $0 \cdot 54$ \\
\hline D. $667-12 / 191 \mathrm{R}$ & 5'-GG GCT AAT CCT TCC TTC CCC-3' & $20 \%$ & $0 \cdot 23$ \\
\hline G. AMAC/137R & 5' TGT TAT CCC CCT CGC AAA 3' & $10 \%$ & $0 \cdot 45$ \\
\hline H. $4 \alpha v s 3 / 210 R$ & 5'-TCT CTT TGC GCC AGA GCT-3' & $10 \%$ & $0 \cdot 45$ \\
\hline I. $407-2 / 209 \mathrm{R}$ & 5'-CT TTG CGT GGG AGC CGG-3' & $20 \%$ & $0 \cdot 23$ \\
\hline J. $253-19 / 175 R$ & 5'-CAA GTG CAC ATT ATG CGG-3' & 0 & $0 \cdot 9$ \\
\hline
\end{tabular}

Use the letters beside each probe in Fig. 1 to compare the probes listed above with the taxa recognized by each probe. See Brinkmeyer et al. (2000) for details of probes shown in Fig. 1 and not listed here.

\section{Fluorescent in situ hybridization (FISH)}

A $4 \mathrm{ml}$ aliquot of the settled water sample plus $40 \mathrm{ml}$ of the corresponding supernatant sample were well mixed to make a total seawater sample of $40 \mathrm{ml}$ and filtered at $15 \mathrm{kPa}$ onto a $0 \cdot 2 \mu \mathrm{m}$ pore-size white polycarbonate membrane (Millipore, Eschborn, Germany), diameter $2.5 \mathrm{~cm}$, with a glass microfibre supporting filter, diameter $2.5 \mathrm{~cm}$ (Whatman, Maidstone, UK) in a glass vacuum filter holder (Sartorius, Göttingen, Germany). Each sample was filtered in duplicate for the in situ hybridizations. One filter was for the hybridization of the Alteromonas-clade probe and its taxon-specific probes. The replicate was for the hybridization of the Roseobacter-clade probe and its taxon-specific probes. The filters were fixed in $4 \%$ paraformaldehyde (PFA) ( $\mathrm{pH} 7 \cdot 2$, freshly made, i.e. not older than 2 weeks, in $1 \times$ phosphate-buffered saline (PBS)) and filter sterilized $(0 \cdot 2 \mu \mathrm{m})$, then incubated overnight at $4{ }^{\circ} \mathrm{C}$ directly in the filter chamber. The samples were rinsed with $10 \mathrm{ml} 1 \times \mathrm{PBS}$ and with $10 \mathrm{ml}$ sterile distilled water. Then the filter was dried at room temperature for $5 \mathrm{~min}$. The upper side of the filter was marked with a pencil. Each filter was dehydrated through a graded ethanol series: $50 \% / 80 \% / 100 \%$ for $5 \mathrm{~min}$ each, then dried at room temperature and cut into four pieces. Each filter quarter was hybridized with two different oligonucleotide probes (Table 1).

The probe combinations on the first filter from each sample were as follows:

Quarter 1: Alteromonas-clade probe/137R, labelled with Cyanin 3 (CY3), a red fluorescent dye and the eubacterial probe 338R, labelled with Fluoresceinisothiocyanate (FITC), a green fluorescent dye (Amann et al., 1995).

Quarter 2: $4 \alpha \mathrm{vs} 3 / 210 \mathrm{R} \mathrm{CY} 3$-labelled and the Alteromonas-clade/137R probe, FITC-labelled.

Quarter 3: 407-2/209R CY 3-labelled and the Alteromonas-clade/137R probe, FITC-labelled.

Quarter 4: 253-19/175 R CY 3-labelled and the Alteromonas-clade/137R probe, FITC-labelled.

The probe combinations on the second filter from each sample were as follows:

Quarter 1: Roseobacter-clade/536R probe CY 3-labelled and the eubacterial probe 338R, FITC-labelled.
Quarter 2: 667-12/191R CY 3-labelled and the Roseobacter-clade 536R probe, FITC-labelled.

Quarter 3: 667-19/1241R CY 3-labelled and the Roseobacter-clade 536R probe, FITC-labelled. 667-19/1241 R is no longer taxon-specific as determined by our most recent probe match searches done during the preparation of this paper.

Quarter 4: 407-20/1446R CY 3-labelled and the Roseobacter-clade 536 probe FITC-labelled.

The 5'-end labelled probes were obtained from MWG (Ebersberg, Germany).

In this manner, each filter quarter was hybridized with a taxon-specific and a higher taxonomic probe. The hybridizations were performed in a $35 \mathrm{~mm}$ Petri dish. Each filter quarter was saturated with $20 \mu$ l hybridization buffer $(20 \mathrm{mM}$ Tris- $\mathrm{HCl} \mathrm{pH} 8.0 ; 0.9 \mathrm{M} \mathrm{NaCl} ; 0.01 \%$ SDS, $x \%$ formamide) $+50 \mathrm{ng} \mathrm{m}^{-1}$ of each oligonucleotide probe $+50 \mathrm{ng} \mathrm{ml}^{-1}$ of competitor probe, if necessary. The formamide concentration varied with each probe and is based on the annealing temperature of the probe to its target (Table 1). Only the Roseobacter-clade probe presents a single mismatch with its closest neighbour and must be used with a competitor probe to block the sites of the nearest neighbours to prevent false positives from occurring (Amann et al., 1990 and references therein). The lid of the Petri dish also contained a filter paper, saturated with hybridization buffer to create a moisture chamber for the hybridization. The dishes themselves were put into another box, which contained more wet tissues to ensure enough humidity for the hybridization. The hybridizations were performed at $46^{\circ} \mathrm{C}$ for $2-3 \mathrm{~h}$ in the dark, to prevent fading of the probes in the light. The hybridization was stopped by adding $5 \mathrm{ml}$ of wash buffer $(20 \mathrm{mM}$ Tris- $\mathrm{HCl} ; \times \mathrm{M} \mathrm{NaCl}$ (where $\mathrm{X}$ is the content of $\mathrm{NaCl}$, replacing the formamide in the hybridization buffer, as given in Table 1); $5 \mathrm{mM}$ EDTA, $0.01 \%$ SDS). The filter pieces were washed two times for $20 \mathrm{~min}$ at $48{ }^{\circ} \mathrm{C}$ with gentle shaking. After the washes, the filter pieces were dipped in sterile distilled water and dried at $48{ }^{\circ} \mathrm{C}$ for $15 \mathrm{~min}$. The filter quarters from one filter were assembled together onto a slide. Counter-staining was performed using $25 \mu \mathrm{l} 4^{\prime}$,6-diamidino-2-phenylindole (DAPI) solution: $1 \mathrm{ml}$ Citifluor (Citifluor Products, Canterbury, UK) $+0.5 \mathrm{ml}$ sterile 
distilled water $+1 \cdot 5 \mu$ DAPI (stock solution $1 \mu \mathrm{g} \mathrm{ml}^{-1}$ ). The quarters were fixed with a coverslip and sealed with nail polish. The slides were viewed with a Zeiss Microscope equipped for epifluorescence microscopy under oil immersion $(\times 1000$ enlargement $)$ with the appropriate filter set (Zeiss filter sets 02,09 and 14). The entire filter quarter was scanned under $\times 1000$ enlargement and all bacteria exhibiting a positive signal were counted. Because of the limited material available for analysis, we did not replicate the counts but instead scanned and counted the entire filter rather than counting replicate fields.

\section{Total bacterial counts}

To count the total bacterial population in the environment sample a similar proportion of settled and supernatant sample was filtered onto a $0 \cdot 2 \mu \mathrm{m}$ pore size black polycarbonate membrane (Millipore, Bedford, MA) as described above. The cells on the filter were fixed in $4 \%$ PFA buffered with $1 \times$ PBS for at least $1 \mathrm{~h}$ at $4{ }^{\circ} \mathrm{C}$. The filters were air-dried and incubated in $80 \%$ ethanol for $5 \mathrm{~min}$. The ethanol bleached the black filters and the bacteria were counted on these filters. The bacteria were counter-stained with DAPI (as above), viewed with a Zeiss microscope equipped with epifluorescence microscopy under oil immersion $(\times 1000$ enlargement) and counted using the DAPI filter set (Zeiss 02). DAPI counts were used for total bacterial counts instead of using counts obtained with the EUB 338R probe because of the small taxonomic limitations of this probe and because of the potential difficulty in detecting cells with low rRNA content in field material.

Total bacterial counts and counts for Alteromonas- and Roseobacter-clade bacteria were very high. Therefore, we counted at least 20 microscope fields in three different areas of the filter pieces rather than scanning the entire filter as we did for the species-specific probe counts, which were rarer events. The total bacterial cell numbers per millilitre were calculated with following formula:

Bacterial numbers $\mathrm{ml}^{-1}=$ Bacteria per microscope field (average) $\times($ effective filter surface/microscope field surface) $/ \mathrm{ml}$ of sample filtered

\section{Statistical analysis}

To determine the correlation between the increase/ decrease in the bacteria and the increase/decrease in cells of Alexandrium spp. and mussel toxicity, we determined the correlation coefficient according to Pearson product moment correlations using the statistical software MINITAB. We tested both untransformed and transformed (square root transformation) correlations of either the total counts for the Roseobacter-clade or Alteromonas-clade bacteria with Alexandrium tamarense counts or with mussel toxicity. To test the correlation of the taxon-specific bacteria with Alexandrium or with mussel toxicity, we determined the correlation of all of the specific bacteria pooled together and with $4 \alpha \mathrm{vs} 3$ alone, because this bacterium was the most abundant of the various bacterial species tested. Significance was tested at the 0.05 level.

\section{Results}

\section{Probes and sampling sites}

Probes to bacteria obtained from PSP-producing dinoflagellates (Brinkmeyer et al., 2000; Hold et al., in press; Table 1, Fig. 1) were successfully applied to Lugol's-fixed water samples. These samples were collected from six sites in the Orkney Isles during 1999 as part of the Scottish phytoplankton monitoring programme (Tables 2, 3 ; Fig. 2). The phylogenetic affiliations of the bacteria for which clade-, genus- and taxon-specific probes were available are shown in Fig. 1. The probes were originally tested for specificity with laboratory cultures employing dot blot and in situ hybridization formats (Brinkmeyer et al., 2000); however some further method development was required before the probes could be applied to Lugol's-fixed water samples. This involved fixing the filters containing the trapped bacteria from the water samples overnight in $4 \%$ PFA in $1 \times$ PBS prior to hybridization and maintaining a good moisture chamber to prevent the filters from drying. This procedure resulted in stronger hybridization signals.

Additionally, as several weeks could elapse between collection of the water samples and analysis, the stability of the bacterial numbers in the water samples was examined. Repeated counts of total bacteria counter-stained with DAPI from water samples at different intervals in a time period over 10 months showed no significant loss in the number of fixed bacteria (see below).

\section{FISH}

The total abundance of bacteria belonging to both Alteromonas- and Roseobacter-clades was determined by counting the number of cells exhibiting a fluorescent signal from the $16 \mathrm{~S}$ rRNA probes. Alteromonas-clade and Roseobacter-clade bacteria and several of the taxon-specific bacteria in these clades were present in the preserved water samples (Figs 3-16).

With water samples from the two main sites (Scapa and String), the total bacterial counts as defined using DAPI staining remained relatively

Fig. 1. Phylogenetic reconstructions using the $16 \mathrm{~S}$ rRNA gene placing the bacteria isolated from various toxic dinoflagellates near their closest neighbours. $(A)$ Roseobacter; $(B)$ Alteromonas. The regions/species recognized by the rRNA probes are highlighted in bold on the trees (redrawn from Brinkmeyer et al., 2000). A, the Roseobacter-clade from the alpha-Proteobacteria; G, the Alteromonas-clade from the gamma-Proteobacteria. See Table 1 for the identification probes associated with the other taxa. 
$\infty$

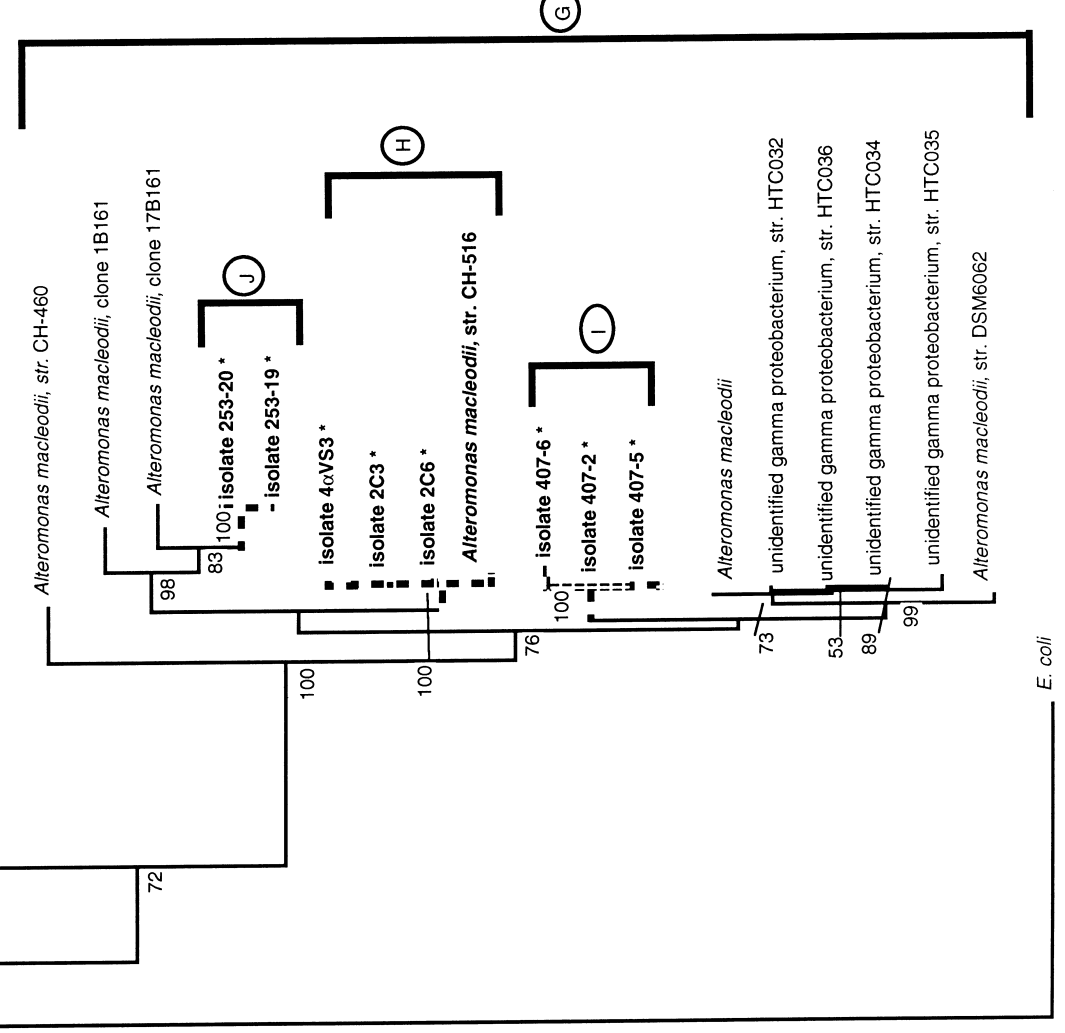

$\stackrel{\circ}{\circ}$

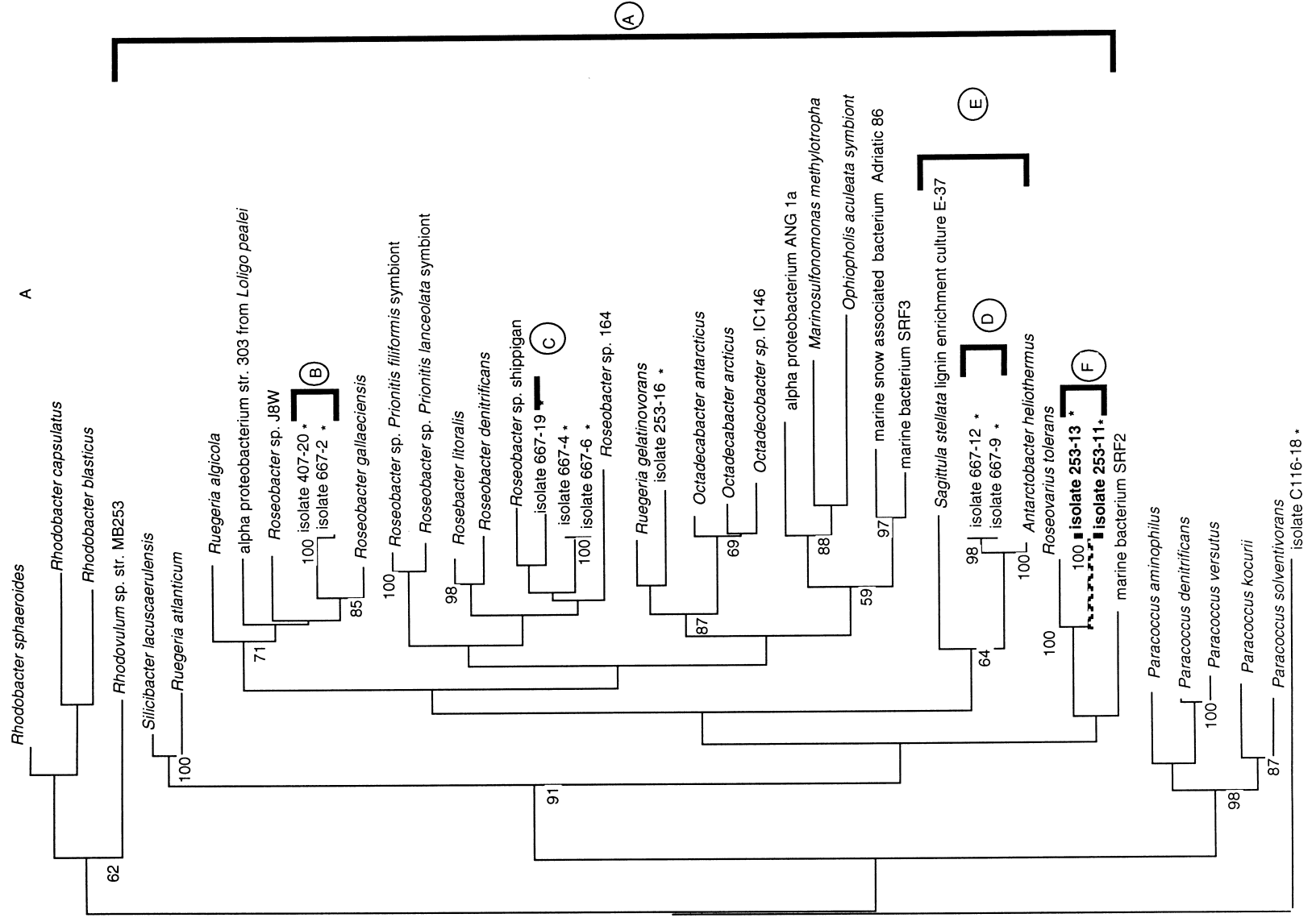

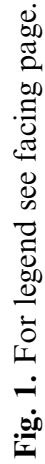


Table 2. Summary of sites and dates in 1999 for which bacterial or algal counts or mussel toxicity were available for this study

\begin{tabular}{|c|c|c|c|c|c|c|c|}
\hline Date & Day no. & Scapa & Gairsay & String & Cava & Clestrain & Yinstay \\
\hline 24 Feb. & 55 & & $\mathrm{X}$ & & & & \\
\hline 8 Mar. & 67 & X A M & & X A & & & \\
\hline 19 Mar. & 78 & & & M & & & \\
\hline 20 Mar. & 79 & M & & & & & \\
\hline 22 Mar. & 81 & X A & & $\mathrm{XA}$ & X A & $\mathrm{X} \mathrm{A}$ & \\
\hline 6 Apr. & 96 & $\mathrm{XAM}$ & & X A M & & & \\
\hline 16 Apr. & 106 & $\mathrm{XA}$ & & $\mathrm{X} \mathrm{A}$ & & & \\
\hline 19 Apr. & 109 & $\mathrm{M}$ & & $\mathrm{M}$ & & & \\
\hline 3 May & 123 & $\mathrm{XA}$ & & X A & & & \\
\hline 14 May & 134 & $\mathrm{X} \mathrm{A}$ & & $\mathrm{X} \mathrm{A}$ & & & \\
\hline 16 May & 136 & $\mathrm{M}$ & & $\mathrm{M}$ & & & \\
\hline 27 May & 147 & A & & X A & & & \\
\hline 1 June & 152 & M & & M & & & \\
\hline 2 June & 153 & X A & & X A & & & \\
\hline 8 June & 159 & $\mathrm{x} \mathrm{M} \mathrm{A}$ & & X A M & & & \\
\hline 15 June & 166 & X A M & & X A M & & & \\
\hline 22 June & 173 & $\mathrm{XAM}$ & M & $\mathrm{XAM}$ & & & \\
\hline 23 June & 174 & & & A & X A M & $\mathrm{X} \mathrm{A}$ & \\
\hline 29 June & 180 & X A M & & X A M & & & \\
\hline 5 July & 186 & $\mathrm{M}$ & & $\mathrm{M}$ & & & \\
\hline 7 July & 188 & $\mathrm{X} \mathrm{A}$ & & X A M & & & \\
\hline 20 July & 201 & $\mathrm{~A}$ & A & A & & & \\
\hline 27 July & 208 & $\mathrm{X} \mathrm{A}$ & & $\mathrm{X} \mathrm{A}$ & & & \\
\hline 30 July & 211 & $\mathrm{X} \mathrm{A}$ & $\mathrm{X}$ & $\mathrm{X}$ & & & $\mathrm{x} A$ \\
\hline 17 Aug. & 229 & $\mathrm{XA}$ & & & & & \\
\hline 24 Aug. & 236 & A & & & & & \\
\hline 7 Sept. & 250 & A & & A & & & \\
\hline 24 Sept. & 267 & A & & A & & & \\
\hline 27 Sept. & 270 & & & A & & & \\
\hline 26 Oct. & 294 & $\mathrm{X} \mathrm{A}$ & & $\mathrm{X} \mathrm{A}$ & & & \\
\hline 10 Nov. & 314 & $\mathrm{X} \mathrm{A}$ & & $\mathrm{A}$ & & & $\mathrm{x}$ \\
\hline
\end{tabular}

Sites marked with an $\mathrm{X}$ represent those where bacterial counts were obtained on that date; those marked with an A represent those where Alexandrium counts were obtained; those marked with an $\mathrm{M}$ are those where mussels were collected for toxicity measurements. Lone Alexandrium counts do not appear in Figs 3-8, whereas lone mussel values on 19 and 20 March were plotted on 22 March, that on 1 June on 2 June, that on 5 July on the 7 July as a 5-15\% reduction in mussel toxicity per day is reasonable if no reinfection occurs (Bricelj \& Shumway, 1998). Other lone mussel values were not plotted.

Table 3. Total counts of bacteria labelled with clade- and species-specific probes at four infrequently sampled sites in 1999

\begin{tabular}{|c|c|c|c|c|c|}
\hline \multirow{2}{*}{$\begin{array}{l}\text { Site and date } \\
\text { Alteromonas-clade bacteria }\end{array}$} & & \multirow[t]{2}{*}{$\begin{array}{l}\text { Total counts } \\
\left(\text { cells } \mathrm{ml}^{-1}\right)\end{array}$} & \multicolumn{3}{|c|}{ Species-specific probes (cells ml ${ }^{-1}$ ) } \\
\hline & & & $4 \alpha \mathrm{vs} 3$ & $407-2$ & $253-19$ \\
\hline \multirow[t]{2}{*}{ Cava } & 22 Mar. & 2200 & 0 & 0 & 0 \\
\hline & 23 June & 13300 & 3 & 13 & 2 \\
\hline Clestrain & 23 June & 2600 & 1 & 10 & 0 \\
\hline Gairsay & 30 July & 5700 & 0 & 0 & 0 \\
\hline Yinstay & 30 July & 1200 & 0 & 0 & 0 \\
\hline Roseobacter-clade bacteria & & & $667-9$ and $667-12$ & $667-19$ & 407-20 and $667-2$ \\
\hline \multirow[t]{2}{*}{ Cava } & 22 Mar. & 2300 & 0 & 0 & 0 \\
\hline & 22 Mar. & 13900 & 39 & 4 & 6 \\
\hline Clestrain & 22 Mar. & 9200 & 0 & 0 & 0 \\
\hline Gairsay & 30 July & 11100 & 0 & 0 & 0 \\
\hline Yinstay & 30 July & 1600 & 0 & 0 & 0 \\
\hline
\end{tabular}

stable (average cell count \pm SD over the entire sampling period): String, $2 \cdot 20 \times 10^{5}$ cells $\mathrm{ml}^{-1} \pm$ $237 \cdot 10$; Scapa, $1 \cdot 43 \times 10^{5}$ cells ml ${ }^{-1} \pm 231 \cdot 5$. One example of the stability of cell counts at one site over time is from Scapa, where the average count $\pm \mathrm{SD}$ over two separate counts taken several months apart was $6.95 \times 10^{4} \pm 500$. In contrast the cell counts for the Alteromonas-clade using clade- 


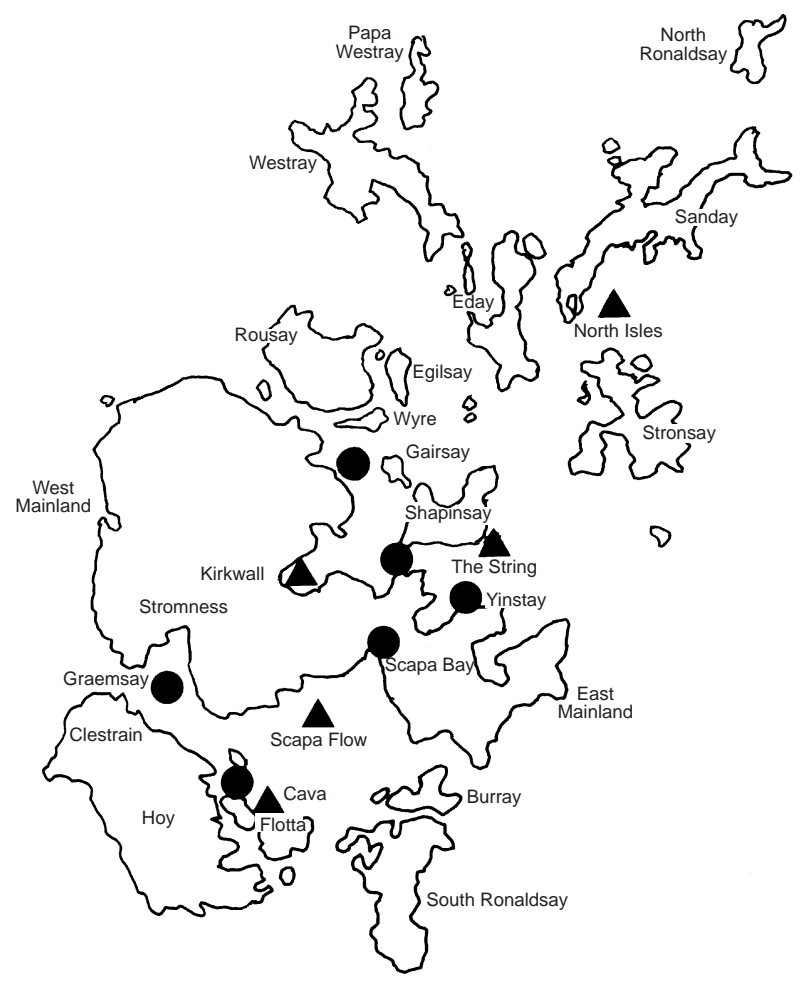

Fig. 2. Detail of the Orkney Islands showing the sites where water samples and mussels were taken and processed as described in the text.

specific probes ranged over the entire sampling period from 0 to $66 \times 10^{3}$ cells $\mathrm{ml}^{-1}$ at String and from 0 to $63 \times 10^{3}$ cells $\mathrm{ml}^{-1}$ at Scapa, representing $30-44 \%$ of the total bacteria at String and Scapa. Similarly, for Roseobacter-clade bacteria as determined by clade-specific probes, counts ranged from 0 to $48 \times 10^{3}$ cells $\mathrm{ml}^{-1}$ at String and from 0 to $54 \times 10^{3}$ cells ml ${ }^{-1}$ at Scapa or about $22-37 \%$ of the total bacterial cells present at the two sites, respectively.

Bacteria belonging to the Alteromonas- and Roseobacter-clades occurred at low levels at both sites in April (days 91-120), accumulated from May (days 121-151) onwards, peaked in June (days 152-181) and dropped markedly in July (days 182-212), with only low numbers detectable in August (days 213-243) through to November (Figs 3, 4). For total counts of Alteromonas-clade bacteria, peak population densities at String occurred about 2 weeks after peak densities at Scapa (Fig. 4). Abundance of individual species basically followed this same pattern, again with maximum bacterial numbers occurring in June with the exception of Alteromonas at String where two peaks in Alteromonas-clade bacteria occurred at Scapa: one in April and another in July (Figs 5-8), although these were an order of magnitude lower than the maximum counts for these bacteria at String.

Although the taxon-specific probes identified populations of both clades, the numbers identified by the species probes were only about $1 \%$ of those detected by the clade probes. Sites other than Scapa and String were randomly sampled during the phytoplankton and shellfish monitoring programmes (Table 2). In the few samples tested, Alteromonas species-specific bacteria were detected at two of the four sites in low numbers whereas particular Roseobacter species were detected at one site, again in low numbers (Table 3).

At the same sites at the Orkney Islands in 1999, toxic Alexandrium spp. counts were obtained by the Scottish phytoplankton monitoring programme (Figs 5-8). At Scapa, Alexandrium exhibited several pulses in abundance during the 1999 sampling season, with highest counts of 240 cells $1^{-1}$ on 2 June 1999 (days 153; Figs 3-6). At String, Alexandrium had only one major maximum of 560 cells $1^{-1}$ on 7 July 1999 (day 188; Figs 3, 4, 7, 8; Table 4). At Scapa, the highest Alexandrium count occurred as numbers of Roseobacter-clade bacteria were increasing (Fig. 3). This resulted in a weak, significant positive correlation between the two data-sets (Table 4). The peak in Alexandrium numbers also coincided with a peak in the Roseobacter species probe for strain 407-20 (Fig. 5). However, there was no significant correlation between the Alexandrium counts and the specific Roseobacter species (Table 4, Fig. 3). The numbers of Alteromonas-clade counts were positively correlated with increasing Alexandrium numbers, which did lead to a weakly significant correlation between the two parameters (Fig. 4, Table 4). For specific Alteromonas species, the highest counts occurred just after the Alexandrium peaks and were negatively but nonsignificantly correlated (Fig. 6, Table 4).

At String, Roseobacter-clade numbers increased as the Alexandrium numbers increased but this correlation was not significant (Fig. 3, Table 4). With the Alteromonas-clade bacteria the same pattern emerged as with Roseobacter-clade; however, in this instance the two were more highly positively correlated, which led to a weakly significant correlation between the Alteromonas-clade and Alexandrium numbers (Fig. 4, Table 4).

At String, peaks of Roseobacter species identified by the probes preceded the peak in Alexandrium numbers by 3 weeks to 1 month (Fig. 7), with a positive but non-significant correlation. Highest Alteromonas species counts at String either coincided with the peak in Alexandrium counts or preceded it by several weeks (Fig. 8). This led to a significant positive correlation between the Alteromonas spp. counts and the Alexandrium numbers (Table 4). Alteromonas strain $4 \alpha \mathrm{vs} 3$ was negatively correlated with Alexandrium spp. at Scapa. However, the number of times at String when this strain was detected was too low (only two positive dates) to permit statistical evaluation of the data. 

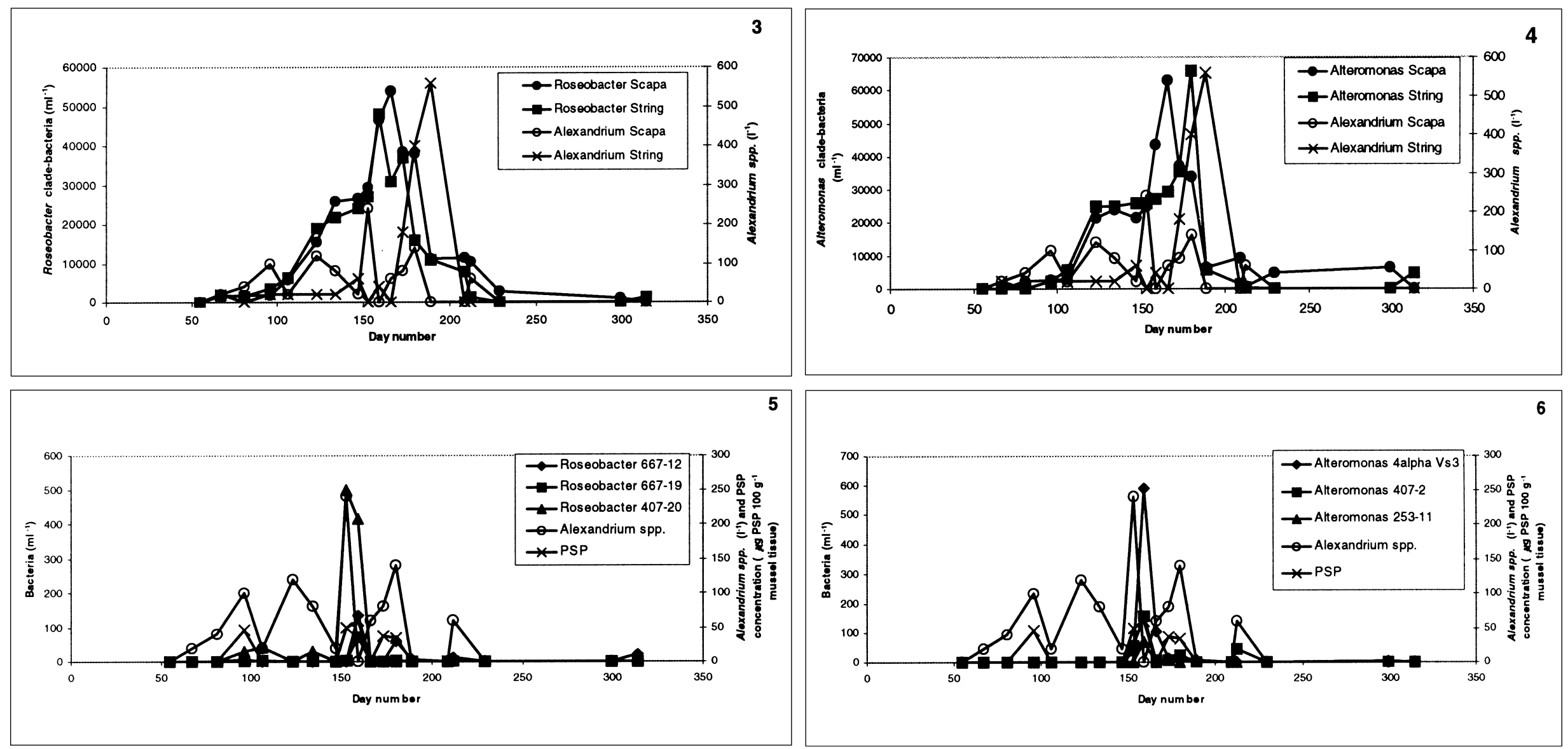

Figs 3-6. Distribution of putatively toxic bacteria in water samples collected at different sites at the Orkney Islands in 1999 as determined by probe hybridization and compared with total Alexandrium counts and mussel toxicity. Fig. 3. Clade-specific counts of Roseobacter-clade bacteria at both String and Scapa. Fig. 4. Clade-specific counts of Alteromonas-clade bacteria at both String and Scapa. Fig. 5. Total counts of bacterial strains 667-2 or 407-20, 667-19 or 667-12 and 667-19, which belong to the Roseobacter-clade, at Scapa compared with total counts of Alexandrium spp. and with PSP concentrations in mussel at Scapa. Fig. 6. Total counts of bacterial strains 4avs3, 407-2 and 253-19, which belong to the Alteromonas-clade, at Scapa compared with total counts of Alexandrium spp. and with PSP concentrations in mussel tissue at Scapa. 

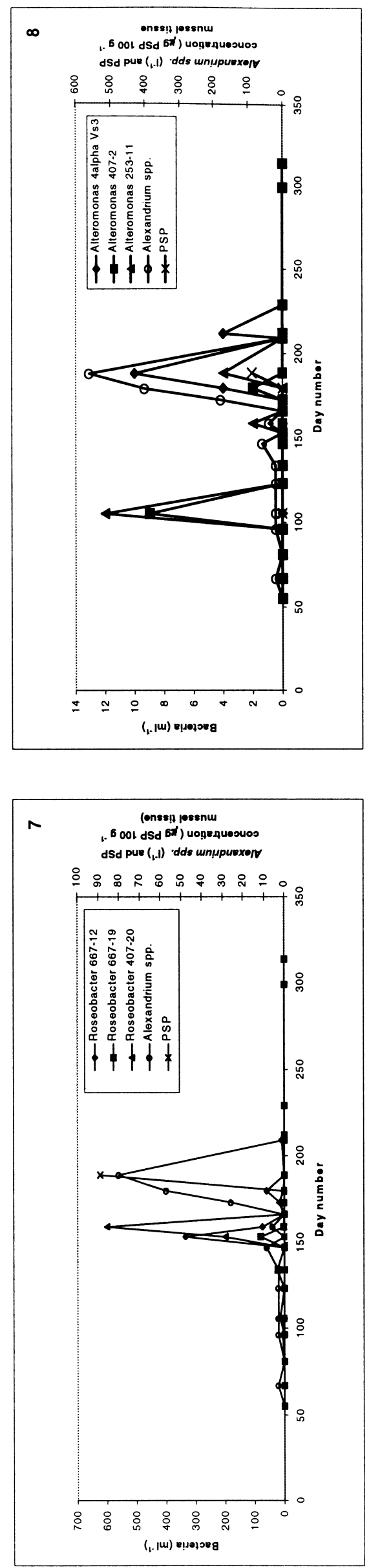

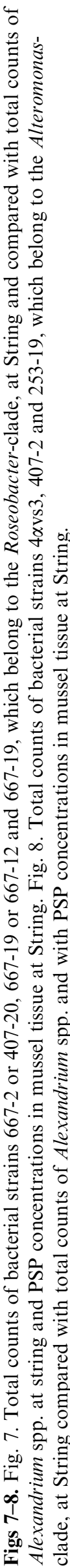

Mussels (Mytilus edulis) from the two main water sampling sites were analysed for PSTs. At Scapa, PSTs were first detected in mussels on 6 April 1999 (day 153) when the Alexandrium numbers first increased (Figs 5, 6). Thereafter mussel toxicity fluctuated alongside that of the dinoflagellate cell numbers, with the highest mussel toxicity being $60 \mu \mathrm{g} 100 \mathrm{~g}^{-1}$ mussel tissue on 8 June 1999 (day 159; Figs 5, 6). One exception to this is that following the high Alexandrium counts on 3 May and 14 May 1999 (days 123, 134), the next mussel sampled, on 16 May (day 136), showed no toxicity. On 8 June 1999, the second highest numbers of Alteromonas- and Roseobacter-clade bacteria were recorded $\left(4.3 \times 10^{4}\right.$ cells ml ${ }^{-1}$ and $4.6 \times 10^{4}$ cells $\mathrm{ml}^{-1}$, respectively. Three purportedly toxic bacteria,

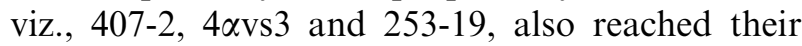
highest numbers on 8 June 1999 at Scapa (Fig. 6). However, of the 12 mussel samples analysed for PSTs only six were obtained on the same day as the water samples, of which two were negative. Therefore, at String there were insufficient data to determine whether there was a significant relationship between the PST concentration in mussels and the Alexandrium or bacterial counts. At Scapa, bacterial numbers detected by both clade and species probes were positively correlated with mussel toxicity but none of these correlations was significant. The toxic bacterium $4 \alpha \mathrm{vs} 3$ was negatively correlated with Alexandrium counts but positively correlated with mussel toxicity, both nonsignificantly.

One month later, on 5 July 1999 (plotted two days later on day 188 in Fig. 8), the highest amount of PSP, $89 \mu \mathrm{g} 100 \mathrm{~g}^{-1}$ mussel tissue, was detected at String, with peak dinoflagellate numbers and Alteromonas species-specific numbers occurring 2 days later (Fig. 8). However, there were insufficiently matched data or positive shellfish samples to determine an association either with Alexandrium or bacterial counts at String. On 7 July 1999 (day 188), the Alteromonas-clade bacterial counts were $5.6 \times$ $10^{3} \mathrm{ml}^{-1}$ and the Roseobacter bacteria were $1 \cdot 1 \times 10^{4} \mathrm{ml}^{-1}$ but the purportedly toxic bacteria were low. Where sufficient data were available to allow a correlation to be calculated, there were no significant correlations between mussel toxicity and the occurrence of bacteria.

\section{Discussion}

Hold et al. (in press) have shown that bacteria associated with laboratory cultures of PST-producing dinoflagellates belong to the alpha and gamma Proteobacteria and the Cytophaga. From the Proteobacteria, bacteria of the Roseobacter-and Alteromonas-clades dominated. This study demonstrates that rRNA probes designed for these bac- 

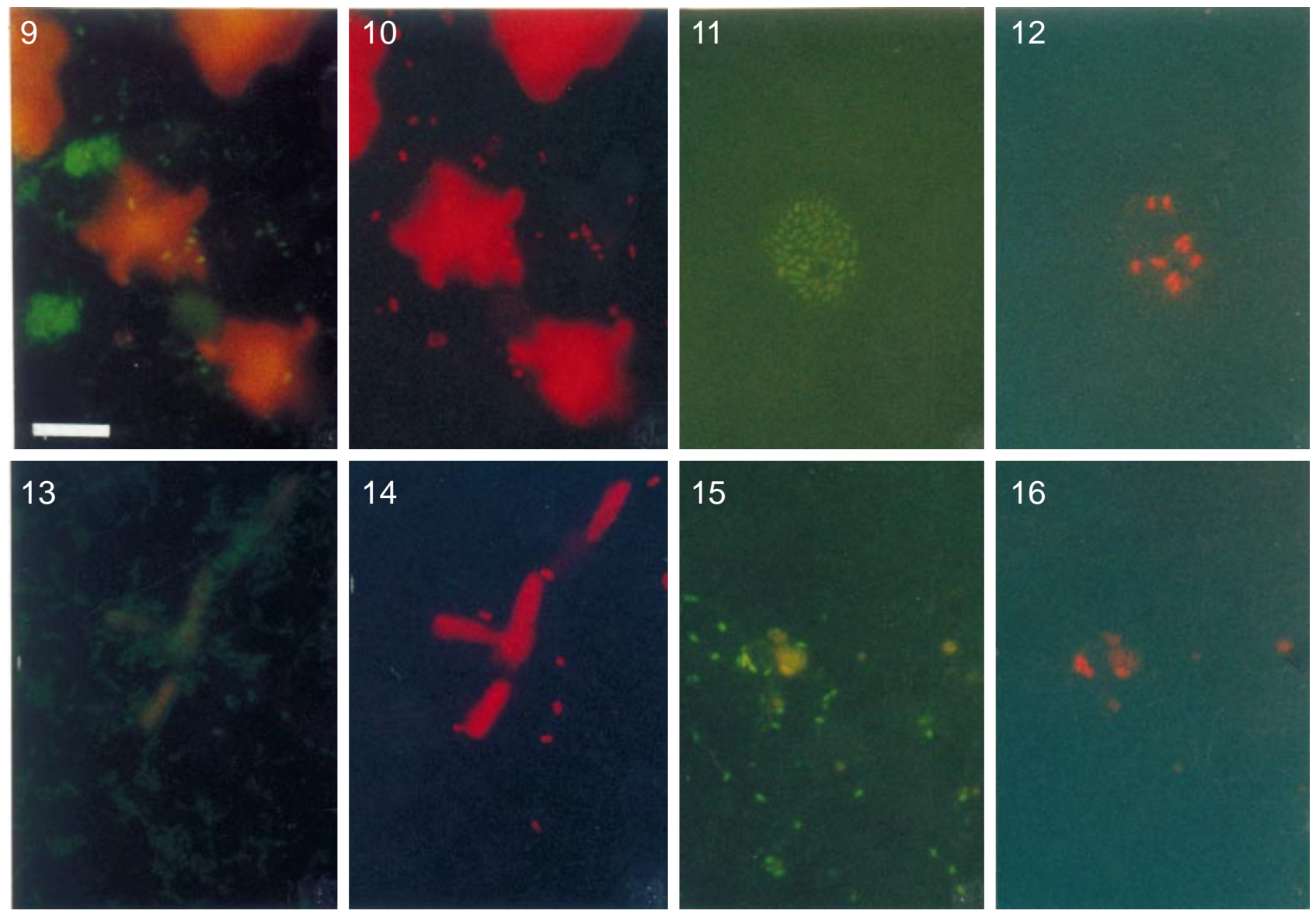

Figs 9-16. Whole cell hybridization of bacteria taken from water samples at the Orkney Islands, summer 1999, and filtered onto $0.2 \mu \mathrm{m}$ white polycarbonate filter. Scale bar represents $10 \mu \mathrm{m}$ and can be applied to all figures. All hybridization steps were performed at $46{ }^{\circ} \mathrm{C}$. Fig. 9. Water samples from Cava hybridized with the Alteromonas-clade/137R probe labelled with FITC. Fig. 10. Same cells hybridized with the probe 407-2/209R labelled with CY3. Fig. 11. Water samples from String hybridized with the universal eubacterial probe EUB 338R labelled with FITC. Fig. 12. Same cells hybridized with the Alteromonas-clade probe 137R labelled with CY3. Fig. 13. Water samples from String hybridized with the Roseobacterclade probe 536R labelled with FITC. Fig. 14. Same cells hybridized with the probe 667-12/994R labelled with CY3. Fig. 15. Water samples at Scapa hybridized with the universal eubacterial probe 338R labelled with FITC. Fig. 16. Same cells hybridized with Roseobacter clade probe 536R labelled with CY3.

Table 4. Summary of Pearson correlations $(R)$ between bacterial counts (square root-transformed), numbers of Alexandrium and mussel toxicity

\begin{tabular}{|c|c|c|c|c|c|c|}
\hline \multirow[b]{2}{*}{ Correlations tested } & \multicolumn{3}{|c|}{ String } & \multicolumn{3}{|c|}{ Scapa } \\
\hline & $R$ & Probability & No. of observations & $R$ & Probability & No. of observations \\
\hline Total Roseobacter vs Alexandrium & $0 \cdot 354$ & $0 \cdot 15$ & 18 & $0 \cdot 479$ & $0 \cdot 783$ & 19 \\
\hline Total Alteromonas vs Alexandrium & $0 \cdot 477$ & $0 \cdot 045^{*}$ & 18 & $0 \cdot 458$ & $0 \cdot 049 *$ & 19 \\
\hline $\begin{array}{l}\text { Pooled Roseobacter taxon-specific } \\
\text { counts vs Alexandrium }\end{array}$ & $0 \cdot 017$ & $0 \cdot 949$ & 17 & $0 \cdot 209$ & $0 \cdot 391$ & 19 \\
\hline $\begin{array}{l}\text { Pooled Alteromonas taxon-specific } \\
\text { counts vs Alexandrium }\end{array}$ & $0 \cdot 585$ & $0 \cdot 017 *$ & 16 & -0.033 & $0 \cdot 893$ & 19 \\
\hline Total Roseobacter vs mussel toxicity & n.a. & n.a. & 5 & $0 \cdot 155$ & $0 \cdot 770$ & 6 \\
\hline Total Alteromonas vs mussel toxicity & n.a. & n.a. & 5 & $0 \cdot 174$ & $0 \cdot 742$ & 6 \\
\hline $\begin{array}{l}\text { Pooled Roseobacter taxon-specific } \\
\text { counts vs mussel toxicity }\end{array}$ & n.a. & n.a. & 5 & $0 \cdot 641$ & $0 \cdot 170$ & 6 \\
\hline $\begin{array}{l}\text { Pooled Alteromonas taxon-specific } \\
\text { counts vs mussel toxicity }\end{array}$ & n.a. & n.a. & 5 & $0 \cdot 358$ & $0 \cdot 486$ & 6 \\
\hline $4 \alpha \mathrm{vs} 3$ vs Alexandrium & n.a. & n.a. & 5 & $-0 \cdot 068$ & $0 \cdot 783$ & 19 \\
\hline $4 \alpha$ vs 3 vs mussel toxicity & n.a. & n.a. & 5 & $0 \cdot 291$ & $0 \cdot 576$ & 6 \\
\hline
\end{tabular}


teria (Brinkmeyer et al., 2000) were successfully used in their detection from Lugol's-fixed water samples obtained from the Orkney Isles, particularly String and Scapa, during the Scottish phytoplankton monitoring programme over the period April to November 1999. The successful application of FISH technology to samples containing Lugol's preservative has not been reported previously and is potentially useful for analysing fresh or archived field samples of both bacteria and algae. We have successfully detected bacteria using FISH in samples from as far back as 1997 (data not shown), but the signal is considerably diminished compared with that obtained in fresh samples in 1999 (Figs 9-13). Therefore, caution must be applied when using the technique described in this paper on archived samples, especially if they have been settled, as not all bacterial cells will settle after 1 week. A possible alternative approach is the use of dot blot hybridizations, as these gave stronger signals than FISH in older samples (data not shown). It may also be possible to improve the FISH signal with a Tyramide signal amplification method (Schönhuber et al., 1997).

At least three Alexandrium species have been reported from waters of the Orkney Isles ( $A$. tamarense, A. ostenfeldii and A. minutum; M. Elbrächter, personal communication) and, although they do co-occur, only one species of the three will dominate at any one time (G. Gerdts, personal communication). The source of these dinoflagellates is unknown; Hummert et al. (2001) suggest that Alexandrium spp. may be carried into Orkney waters from the open ocean by currents, as determined by drift buoy experiments conducted at single time points in 1999 and 2000 (G, Gerdts, personal communication). Certainly counts 100 times greater than those reported here have been found both north-west and south-east of the Orkney Islands. Conversely, Alexandrium cysts have been detected in the area, thereby providing potential seed beds for the vegetative dinoflagellate cells (E. Macdonald, personal communication). Nevertheless, Alexandrium spp. and shellfish contaminated with PSTs (G. Howard, personal communication) occur yearly in this area, and are why this site was chosen for this study.

Our work utilized data and samples from a monitoring programme that operates, and is modified throughout the season, to meet regulatory authority requirements. We also used clade-specific probes to the genera Roseobacter and Alteromonas and species-specific probes for each clade.

The Roseobacter species-specific probes were designed to bacteria closely related to Antarctobacter heliothermus (667-12), and to a further two bacteria more closely related to Roseobacter $\mathrm{sp}$., Roseobacter sp. Shippigan strain (667-19) and Roseobacter gallaeciensis (407-20) (Brinkmeyer et al., 2000; Fig. 1). The species-specific probes for the Alteromonas-clade consisted of probes to three different unclassified Alteromonas species (Fig. 1). All these bacteria were previously isolated from Alexandrium cultures taken from different parts of the world (Hold et al., in press).

As bacteria cross-reacting with the probes were easily detected, this would suggest that they were actively growing members of the bacterioplankton. However, a word of caution is warranted. As the vast majority of marine bacterial diversity remains undescribed it is feasible that the probes may have targeted as yet unknown, perhaps closely related bacteria with the same target sequence. Nevertheless, given that the probes were designed to the highest possible specificity given the information currently available in GenBank databases the observations detailed below are considered valid.

Bacteria reacting to probes for the Roseobacterand Alteromonas-clades were common, consisting of up to $46 \%$ of the total bacterial population. However, the number of bacteria cross-reacting to the species-specific probes were approximately $1 \%$ of the number detected by the clade probes. This indicates there is a large percentage of the bacterial community belonging to these two clades that could not be accounted for using the taxon-specific probes.

There was a weak significant positive relationship between Alteromonas- and Roseobacter-clade counts and those of Alexandrium spp. at Scapa Flow. At String there was also a weak correlation between Alexandrium and the Alteromonas clade counts but not the Roseobacter-clade. Interestingly, at String, there was also a significant relationship between the pooled Alteromonas species-specific counts (which are purportedly toxic strains), although the bacterial numbers were relatively low. Data were not available on the rest of the phytoplankton community and therefore we were unable to determine whether any relationship existed between the bacteria and other phytoplankton species.

Other researchers have shown that Roseobacter and Alteromonas bacterial clades are relatively common in the marine environment (Glazebrook et al., 1996; Gonzalez \& Moran, 1997; Acinas et al., 1998) although few have investigated their occurrence over time and in relation to dinoflagellate species. Kerkhof et al. (1999) have shown that bacteria associated with algal bloom populations are not the same as those found under non-bloom conditions and they inferred from their study that certain groups of bacteria and phytoplankton were tightly coupled in time and space. Chilean isolates of $A$. catenella were infected by a variety of gramnegative bacteria including species from the genera Pseudomonas, Aeromonas, Flavobacterium, Pasteur- 
ella, Proteum and Moraxella-like, some of which were shown to produce PSTs (Córdova et al., 2001). Other studies have documented the co-occurrence of similar bacterial genera, such as Aeromonas, Pseudomonas and Vibrio, from within a bloom of dinoflagellates producing red tides (Buck \& Pierce, 1989; Romalde et al., 1990). Some bacterial isolates from the bloom and from algal cultures established from the bloom exhibited cytotoxicity (Buck \& Pierce, 1989; Romalde et al., 1990). Evans (1973, cited in Buck \& Pierce, 1989) postulated a red tide cycle involving (1) initial bacterial growth simulated by organic and inorganic nutrients, the bacterial populations then providing vitamins to stimulate red tide blooms, (2) other bacteria growth stimulated by dying, decaying target organisms in the red tide bloom, (3) toxins from bacteria working synergistically with the algal toxins to kill fish or toxify shellfish and (4) the cycle perpetuating itself.

Recent investigations of bacterial interactions with HAB species have begun to reveal the complexity of these associations. These describe how bacteria influence algal toxin concentrations and are involved in the decline of algal blooms (see reviews in Doucette, 1995; Plumley, 1997; Doucette et al., 1998; Gallacher \& Smith, 1999). However, little information is available with regard to the identity of bacterial populations during the occurrence of toxic Alexandrium species in the environment. Babinchak et al. (1998) compared bacterial composition at the class level between toxic and non-toxic strains of $A$. tamarense, between toxic species of Alexandrium and between toxic strains of the same species taken from different geographic locations. They found different bacterial associations within each level of comparison. Our study infers an association between bacteria of the Roseobacter- and Alteromonas-clades and some specific Alteromonas species to numbers of Alexandrium cells. It is noteworthy that there is a cooccurrence in time between $A$. tamarense and bacteria believed to live in some kind of relationship with these algae, but these bacteria may be specific to the hosts from which they were originally isolated, which are from other parts of the world. Córdova et al. (2001) also inferred from their western blot data that bacterial infection of $A$. catenella was clone-specific, and their work also suggested that some dinoflagellate clones were more susceptible to bacterial infection than others. Further investigations are required to determine whether these specific bacteria are involved in the increase and decline of Alexandrium and its production of PSTs. The latter is particularly pertinent given that bacteria isolated from dinoflagellates can biotransform PSTs (Smith et al., 2001). We therefore plan to conduct further studies over an additional monitoring period using the probes to investigate this association in more detail. Laboratory investigations are planned to examine the spatial relationship between the bacteria and algae using these probes and confocal microscopy.

Questions also arise with regard to the association of bacteria with shellfish toxicity. At the outset of this study plans also included examining the relationship between the Alexandrium numbers, bacterial counts and the concentration of PST in shellfish. However, the adaptive nature of the monitoring programme coupled with the fact that the occurrences of PSTs were lower in 1999 than in previous years (G. Howard, personal communication) meant that there were too few samples taken on the same dates as water samples to allow any inference to be reached. All that can be stated is that the specific bacteria were present during periods when the mussels contained PSTs and the changes in their numbers were positively correlated. Again further work is planned on this aspect at a later date, but it is obvious that a well integrated sampling program must be carried out if any meaningful correlations are to be uncovered. This is an important aspect given that bacteria isolated from shellfish have also been shown to biotransform PSTs (Smith et al., 2001) and hence potentially influence shellfish toxicity. In future environmental studies it would also be of interest to examine shellfish tissue for bacteria using the probes. We have developed in situ hybridization using enzymatic, colorimetric detection as well as conventional FISH detection for detecting Alteromonas spp. and Roseobacter spp. in paraffin-embedded mussel hepatopancreas (K. Töbe et al., unpublished), and this technique will be used in further environmental studies.

In conclusion the data presented in this paper are the most comprehensive to date with regard to examining which bacteria, including purportedly toxic bacteria, are present in the water column during periods of shellfish toxicity and when Alexandrium spp. are present. This work is the first step in studying bacterial/dinoflagellate interactions in terms of PSTs in the environment. However, conclusive evidence on the influence of bacteria in relation to the occurrence of PSTs in dinoflagellates and shellfish awaits information on what genes are involved in the production of PSTs and the environmental parameters that trigger them.

\section{Acknowledgements}

The work was funded by the EU FAIR Project FAIR CT 961558 and the FRS, Marine Laboratory, Aberdeen. We thank Mrs Helga Mehl, Sheila Fraser and Faye Grant for technical assistance. We thank Dr A. Shanks for performing the 
statistical analysis of the data. Dr K. Valentin and Dr. W. Kooistra critically read the manuscript.

\section{References}

Acinas, S.G., Anton, J. \& Rodriguez-Valera, F. (1999). Diversity of free-living and attached bacteria in offshore western Mediterranean waters as depicted by analysis of genes encoding 16S rRNA. Appl. Environ. Microbiol., 65: 514-522.

Amann, R.I., Binder, B.J., Olson, R.J., Chisholm, S.W., Devereux, R. \& Stahl, D.A. (1990). Combination of 16 S rRNA targeted oligonucleotides with flow cytometry for analyzing mixed microbial populations. Appl. Environ. Microbiol., 56: 1919-1925.

Amann, R., Ludwig, W. \& Schleifer, K.H. (1995). Phylogenetic identification and in situ detection of individual microbial cells without cultivation. Microbiol. Rev., 59: 143-169.

Amann, R.I., Ludwig, W., Schulze, R., Spring, S., Moore, E. \& SCHLEIFER, K.H. (1996). rRNA-targeted oligonucleotide probes for the identification of genuine and former Pseudomonads. Syst. Appl. Microbiol., 19: 501-509.

AOAC (1990). Official methods of Analysis (Hellrich, K., ed.), 881-882. Association of official Analytical Chemists. 15th ed., Washington, D.C.

BabinchaK, J.A., McGovern, E.R. \& Doucette, G.J. (1998). Isolation and characterization of the bacterial flora associated with PSP-related dinoflagellate species. In Harmful Algae (Reguera, B., Blanco, J., Fernandez, M.L. \& Wyatt, T., editors), 410-413. Xunta de Galicia \& Intergovernmental Oceanographic Commission of UNESCO, Grafisant, Spain.

Bates, S.S., Douglas, D.J., Doucette, G.J. \& Leger, C. (1995). Enhancement of domoic acid production by reintroducing bacteria to axenic cultures of the diatom Pseudo-nitzschia multiseries. Nat. Toxins, 3: 428-435.

Bricelj, M. \& Shumway, S. (1998). Paralytic shellfish toxins in bivalve molluscs: occurrence, transfer, kinetics and biotransformation. Rev. Fish. Sci., 6: 315-383.

Brinkmeyer, R., Rappé, M., Gallacher, S. \& Medlin, L.K. (2000). Toxic dinoflagellates and their associated bacteria: development of clade- (Roseobacter and Alteromonas) and taxonspecific oligonucleotide probes to study bacterial/toxic algal interactions. Eur. J. Phycol., 35: 315-331.

BuCK, J.D. \& PIERCE, R.H. (1989). Bacteriological aspects of Florida red tides: a revisit and newer observations. Estuarine Coastal Shelf Sci., 29: 317-326.

Cembella, A.D. (1998). Ecophysiology and metabolism of paralytic shellfish toxins in marine microalgae. In Physiological Ecology of Harmful Algal Blooms (Anderson, D.M., Cembella, A.D. \& Hallegraeff, G.M., editors), 381-403. NATO ASI series vol. G41, Springer, Berlin.

Córdova, J., Cárdenas, L., Cárdenas, L. \& Yudelivich, (2001). Multiple bacterial infection of Alexandrium catenella (Dinophyceae) J. Plankton Res., in press.

Costerton, J.W., Lewandowski, Z., Caldwell, D.E., Korber, D.R. \& Lappin-ScotT, H.M. (1995). Microbial biofilms. Annu. Rev. Microbiol., 49: 711-745.

DoucetTe, G.J. (1995). Interactions between bacteria and harmful algae: a review. Nat. Toxins, 3: 65-74.

Doucette, G.J. \& Powell, C.L. (1998). Algal-bacterial interactions: can they determine the PSP-related toxicity of dinoflagellates?. In Harmful Algae (Reguera, B., Blanco, J., Fernandez, M.L. \& Wyatt, T., editors), 406-409. Xunta de Galicia \& Intergovernmental Oceanographic Commission of UNESCO, Grafisant, Spain.

DoucetTe, G.J. \& TRICK, C.G. (1995). Characterization of bacteria associated with different isolates of Alexandrium tamarense. In Harmful Marine Algal Blooms (Lassus, P., Arzul, G., Erard, E., Gentien, P. \& Marcaillou, C., editors), 33-38, Lavoisier, Paris.

Doucette, G.J., Kodama, G., Franca, S. \& Gallacher, S. (1998). Bacterial interactions with harmful algal bloom species: bloom ecology, toxigenesis and cytology. In Physiological Ecology of Harmful Algal Blooms (Anderson, D.M., Cembella, A.D. \&
Hallegraeff, G.M., editors), 619-646. NATO ASI series vol. G41, Springer, Berlin.

Franca, S., Viegas, S., Mascarenhas, V., Pinto, L. \& Doucette, G.J. (1995). Prokaryotes in association with a toxic Alexandrium lusitanicum in culture. In Harmful Marine Algal Blooms (Lassus, P., Arzul, G., Erard, E., Gentien, P. \& Marcaillou, C., editors), 45-51. Lavoisier, Paris.

Franca, S., Pinto, L., Alvito, P., Sousa, I., Vasconcelos, V. \& DoucetTE, G.J. (1996). Studies on prokaryotes associated with PSP producing dinoflagellates. In Harmful and Toxic Algal Blooms (Yasumoto, T., Oshima, Y. \& Fukuyo, Y., editors), 347-350. International Oceanographic commission of UNESCO.

Gallacher, S. \& Birkbeck, T.H. (1995). Isolation of marine bacteria producing sodium channel blocking toxins and the seasonal variation in their frequency in seawater. In Harmful Marine Algal Blooms (Lassus, P., Arzul, G., Erard, E., Gentien, P. \& Marcaillou, C., editors), 445-450. Lavoisier, Paris.

Gallacher, S. \& Smith, E.A. (1999). Bacteria and paralytic shellfish toxins. Protist, 2: 245-255.

Gallacher, S., Flynn, K., Leftley, J., Lewis, J., Munro, P.D. \& BIRKBECK, T.H. (1996). Evidence for the production of paralytic shellfish toxins by bacteria associated with Alexandrium spp. (Dinophyta) in culture. In Harmful and Toxic Algal Blooms (Yasumoto, T., Oshima, Y. \& Fukuyo, Y., editors), 355-358. Intergovernmental Oceanography Commission of UNESCO.

Gallacher, S., Flynn, K.J., Franco, J.M., Brueggemann, E.E. \& Hines, H. (1997). Evidence for production of paralytic shellfish toxins by bacteria associated with Alexandrium spp. (Dinophyta) in culture. Appl. Environ. Microbiol., 63: 239-245.

Glazebrook, P.W., Moriarity, D.J.W., Hayward, A.C. \& MACRAE, I.C. (1996). Seasonal changes in numbers and the location of a particular bacterial strain of Alteromonas sp. in seagrass sediments. Microb. Ecol., 31 : 1-13.

GonZaLeZ, J.M. \& Moran, M.A. (1997). Numerical dominance of a group of marine bacteria in the alpha subclass of the class Proteobacteria in coastal seawater. Appl. Environ. Microbiol., 63: 4237-4242.

Hold, G.L., Smith, E.A., Rappe, M.S., Mass, E.W., Moore, E.R., Stroempl, C., Stephens, J., Birckbeck, T.H. \& Gallacher, S., 2001. Characterization of bacterial communities associated with toxic and non-toxic dinoflagellates: Alexandrium spp. and Scrippsiella trochoidea. FEMS Mol. Ecol., in press.

Hummert, C., Gerdts, G., Schütt, C. \& Luckas, B. (2001). PSP toxin content in algal blooms and mollusks in coastal waters around the Orkney Islands and the East Coast of Scotland. In Proceedings of the 9th International Conference on Harmful Algal Blooms (Hallegraeff, G., Cembella, A. \& Boalch, C., editors), in press.

KaO, C.Y. (1993). Paralytic shellfish poisoning. In Algal Toxins in Seafood and Drinking Water (Falconer, E.R., editor), 75-85. Academic Press, London.

Kerkhof, L.J., Voytek, M.A., Sherrell, R.M., Millie, D. \& SCHOFIELD, O. (1999). Variability in bacterial community structure during upwelling in the coastal ocean. Hydrobiologia, 401: 139-148.

Kodama, M. (1990). Possible links between bacteria and toxin production in algal blooms. In Toxic Marine Phytoplankton (Granéli, E., Sundström, B., Edler, L. \& Anderson, D.M., editors), 52-61. Elsevier, New York.

Kodama, M., Ogata, T. \& Sato, S. (1988). Bacterial production of saxitoxin. Agric. Biol. Chem., 52: 1075-1077.

Kodama, M., Ogata, T., Sakamoto, S., Sato, S., Honda, T. \& Miwatani, T. (1990a). Production of paralytic shellfish toxins by a bacterium Moraxella sp. isolated from Protogonyaulax tamarensis. Toxicon, 28 : 707-714.

Kodama, M., Ogata, T., Sato, S. \& Sakomoto, S. (1990b). Possible association of marine bacteria with paralytic toxicity in bivalves. Mar. Ecol. Prog. Ser., 61: 203-206.

Kopp, M., Doucette, G.J., Kodama, M., Gerdts, G., Schütt, C. \& MeduIn, L.K. (1997). Phylogenetic analysis of selected toxic and non-purportedly toxic bacterial strains isolated from the 
toxic dinoflagellate Alexandrium tamarense. FEMS Microbiol. Ecol., 24: 252-257.

Kotaki, Y., Oshima, Y. \& Yasumoto, T. (1985a). Bacterial transformation of paralytic shellfish toxins in coral reef crabs and a marine snail. Bull. Jpn. Soc. Sci. Fish., 51: 1009-1013.

Kotaki, Y., Oshima, Y. \& Yasumoto, T. (1985b). Bacterial transformation of paralytic shellfish toxins. In Toxic Dinoflagellates (Anderson, D.M., White, A.W. \& Baden, D.G., editors), 287-292. Elsevier, Amsterdam.

Lafay, B., Ruimy, R., Detraubenberg, C.R., Breitmayer, V., GAUthier, M. J. \& Christen, R. (1995). Roseobacter algicola $\mathrm{sp.}$ nov., a new marine bacterium isolated from the phycosphere of the toxin producing dinoflagellate Prorocentrum lima. Int. J. Syst. Bacteriol., 45: 290-296.

Legrand, C. \& CARlsSon, P. (1998). Uptake of high molecular weight dextran by the dinoflagellate Alexandrium catenella. Aquat. Microb. Ecol., 16: 81-86.

Levasseur, M., Monfort, P., Doucette, G.J. \& Michaud, S. (1996). Preliminary study of bacteria as PSP producers in the Gulf of St. Lawrence, Canada. In Harmful and Toxic Algal Bloom (Yasumoto, T., Oshima, Y., \& Fukuyo, Y., editors), 363-366. Intergovernmental Oceanographic Commission of UNESCO.

Lewis, J., Kennaway, G., Franca, S. \& Alverca, E. (2000). Bacterial:dinoflagellate interactions: investigated microscopy of Alexandrium (abstract). In Ninth International Conference on Harmful Algal Blooms, Hobart, Tasmania, p. 164.

Mahmood, N.A. \& Carmichael, W.W. (1986). Paralytic shellfish poison produced by the freshwater cyanobacterium Aphanizomenon flos-aquae NH-5. Toxicon, 24: 175-186.

Negri, A.P., Jones, G.J., Blackburn, S.I., Oshima, Y. \& ONODERA, H. (1997). Effect of culture and bloom development and of sample storage on paralytic shellfish poisons in the cyanobacterium Anabaena circinalis. J. Phycol., 33: 26-35.

Ogata, T., Kodama, M., Komaru, K., Setsuko, S., Sato, S. \& Simidu, U. (1990). Production of paralytic shellfish toxins by bacteria isolated from toxic dinoflagellates. In Toxic Marine Phytoplankton (Granéli, E., Sundström, B., Edler, L. \& Anderson, D.M., editors), 311-314. Elsevier, New York.
Onodera, H., Satake, M., Oshima, Y., Yasumoto, T. \& CARmichael, W.W. (1997). New saxitoxin analogues from the freshwater filamentous cyanobacterium Lyngbya wollei. Nat. Toxins, 5: 146-151.

Oshima, Z. (1995). Post-column derivatization HPLC methods for paralytic shellfish poisons. In Manual on Harmful Marine Microalgae (Hallegraeff, G.M., Anderson, D.M. \& Cembella, A.D., editors), 81-94. IOC Manuals and Guides no. 33, UNESCO, Paris.

Provic, I., Brümmer, F., Brigge, T., Görtz, H.D., Gerdts, G., SChÜtt, C., ElbräChter, M. \& MÜLler, W.E.G. (1998). Bacteria of the genus Roseobacter associated with the toxic dinoflagellate Prorocentrum lima. Protist, 149: 347-357.

Plumley, G. (1997). Marine algal toxins: biochemistry, genetics and molecular biology. Limnol. Oceanogr., 42: 1252-1264.

Rausch de Traubenberg, C. \& Soyer-Gobillard, M.O. (1990). Bacteria associated with a photosynthetic dinoflagellate in culture. Symbiosis, 8: 117-133.

Romalde, J.L., Barja, J.L. \& Toranzo, A.E. (1990). Vibrios associated with red tides caused by Mesodinium rubrum. Appl. Environ. Microbiol., 56: 3615-3619.

Sakamoto, S., Ogata, T., Sato, S., Kodama, M. \& Takeuchi, T. (1992). Causative organism of paralytic shellfish toxins other than toxic dinoflagellates. Mar. Ecol. Prog. Ser., 89: 229-235.

Schönhuber, W., Fuchs, B., JuRetschKo, S. \& Amann, R. (1997). Improved sensitivity of Whole-Cell Hybridization by the Combination of Horseradish Peroxidase-labeled Oligonucleotides and Tyramide Signal amplification. Appl. Environ. Microbiol., 63: 3268-3273.

SILVA, E.S. (1982). Relationship between dinoflagellates and intracellular bacteria. In Proceedings of the IV IUPAC Symposium on Mycotoxins and Phycotoxins, 8. Pathotox. Publications.

Smith, E.A., Grant, F., Ferguson, C.M.J. \& Gallacher, S. (2001). Biotransformations of paralytic shellfish toxins by bacteria isolated from bivalve molluscs. Appl. Environ. Microbiol., 67: 2345-2353.

Throndsen, J. (1978). Preservation and storage. In Phytoplankton Manual (Sournia, A., editor), 69-74. UNESCO, Paris. 